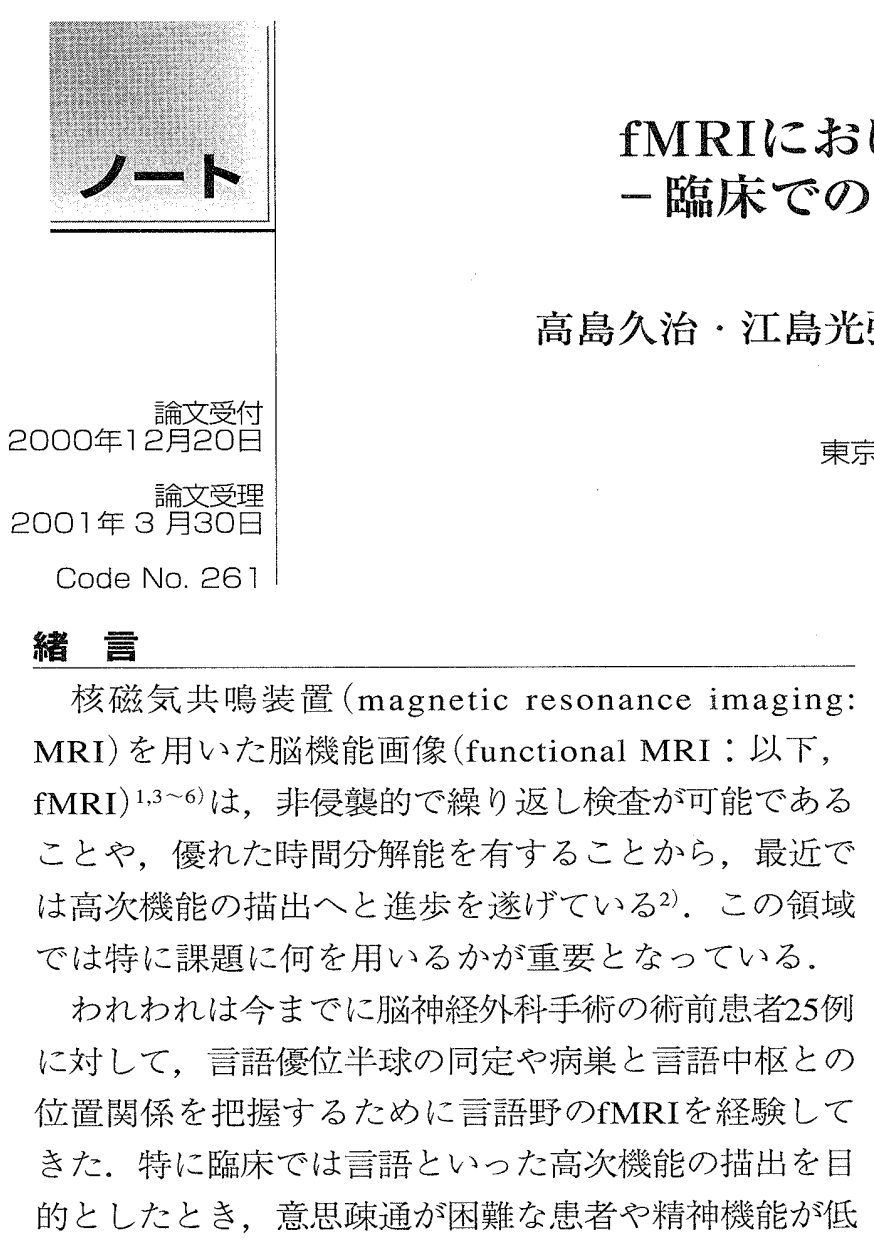

下している患者，また失語を伴った患者等も含まれる ため, 課題の設定は重要な位置を占めると思われる。 今までの研究の大半が健常者を対象としたものであ り, 臨床例での検討は少ない.さらに, 課題の重要性 は言及されてはいるものの具体的にどのような課題が よいのか記述された文献はほとんどない。また，言語 野の描出に「しりとり」を用いた報告7,8)が多いが，われ われの経験では対象者にとって課題達成の点で適した ものとはいえない場合があった。

今回われわれは，fMRIを用いて言語優位半球の同 定や病巣と言語中枢との位置関係の把握をする場合, 臨床における課題設定のポイントについて検討した。

\title{
Points in the Set-up of Tests for fMRI: Toward the Delineation of Language-competent Areas in Clinical Practice
}

\section{HISAHARU TAKASHIMA, MITSUHIRO EJIMA, MAMORU TAKEYAMA, MASAMI YAMAGUCHI, and YOSHINO SATO}

Department of Radiology. Tokyo Women's Medical University Hospital

Received Dec. 20, 2000; Revision accepted March 30, 2001; Code No. 261

\section{Summary}

This hospital has performed fMRI of language-competent areas of the brain to identify the language-dominant hemisphere and obtain the configuration of the focus in the language-dominant side of the brain. Until now, signals have been detected in only two of fifteen patients who were diagnosed by language tests of a lastsyllable word chain. In the present experiment, we tried to have subjects select the type of test. The result was that changes in signals were detected in eight of ten patients. Although the set-up of tests for fMRI is said to hold significant value, clear-cut studies to back this up have rarely been seen. Because clinical medicine treats patients who have difficulty in communication or suffer from aphasia, it is important to take into consideration individual variations and to set up a test suitable for, or achievable by, these individuals. The present method enabled us to avoid failure in examination caused by unsuccessful tests.

Key words: Functional magnetic resonance imaging $(f M R I)$, Blood oxygen level dependent $(B O L D)$, Language, TASK

別刷資料請求先：干162-8666 東京都新宿区河田町8-1

東京女子医科大学病院 放射線部 高島久治 宛

2001 年 6 月 
Table 1 Subjects and numbers.

\begin{tabular}{ccc}
\hline \hline TASK & Healthy subjects & Clinical cases \\
\hline Last-syllable word chain & 1 & 2 \\
Pronounce the & 3 & 1 \\
Japanese syllabary & & \\
Giving one's name & 1 & 1 \\
Counting aloud & 1 & 5 \\
A stimulus of the language & 4 & \\
by hearing & & - \\
Animal name remembrance & - &
\end{tabular}

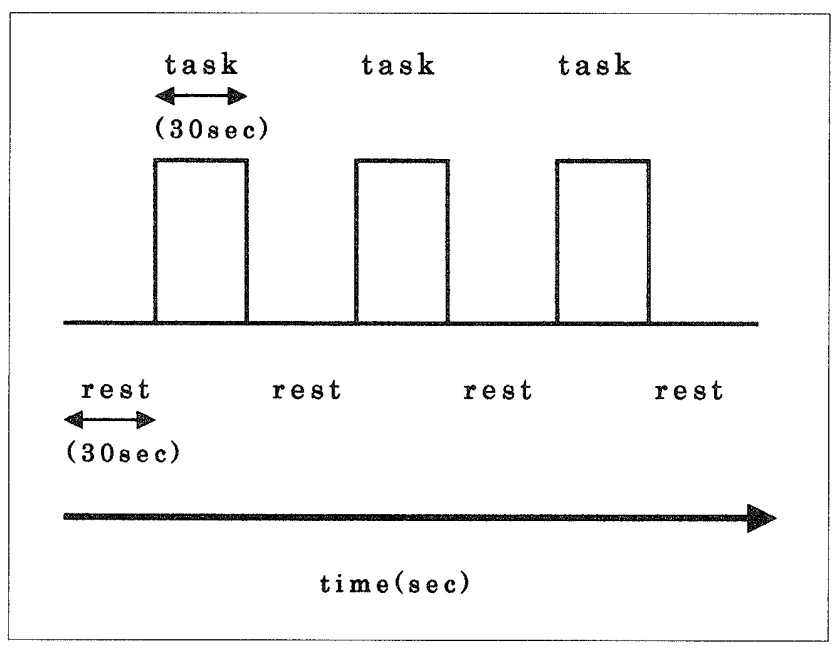

Fig. 1 Conceptual figure of the box-car paradigm.

\section{1. 方 法}

\section{1-1 対象者}

対象者は健常成人男性 10 例(全員右利き)，術前の患 者25例（男性17例, 女性 8 例，全員右利き，年齢構成 は10歳代 3 例，20歳代 12 例，30歳代 3 例，50歳代 6 例，70歳代 1 例)である。まず健常者にて，今回想定 した各課題において信号変化がとらえられることと， 各課題による賦活部位を確認してから患者に摘要し た.今回の検討では，課題が不成功になることを防ぐ ために各自が達成できるように，与える課題を対象者 に選択してもらう方法をとった。術前の患者25例のう ち10名には課題を選択させて言語野の描出を試みた。 また「しりとり」を課題とした術前の患者15例との比 較検討を行った。「単純」な課題を想定し，対象者が課 題として選んたものとその内訳はTable 1の通りである (課題のうち，数唱は 1 ～ 10 までの数字をランダムに 唱える=self-ordered TASK，聴覚性言語刺激は雑誌の 記事の朗読を聞かせた)。なお，「しりとり」の15例と 課題を選択した10例の病巣の局在部位をTable 2 に示 与.
Table 2 Items of an existence part.

\begin{tabular}{lcc}
\hline \hline \multicolumn{1}{c}{ Existence part } & Last-syllable word chain & Selected TASK \\
\hline Right frontal lobe & 7 & 1 \\
Right temporal lobe & 4 & 2 \\
Right parietal lobe & 0 & 1 \\
Left frontal lobe & 3 & 2 \\
Left temporal lobe & 1 & 4 \\
\hline
\end{tabular}

\section{1-2 使用装置およびデータ収集条件}

使用した装置はGE社製1.5T(テスラ)臨床用MRI Signa Horizon LX Ver. 8.2 (最大傾斜磁場強度 $23 \mathrm{mT} / \mathrm{m}$, スリューレート $120 \mathrm{mT} / \mathrm{m} / \mathrm{ms})$. RFコイルは標準head 用コイル。データ収集は，グラディエントエコー型 EPI (TR 2,000ms, TE50ms, フリップアングル90度, 64×64マトリクス，FOV240mm，スライス厚 $8 \mathrm{~mm}$, スライスギャップ $2 \mathrm{~mm}$ ，バンド幅 $62.5 \mathrm{kHZ)のBOLD}$ 法 (blood oxygenation level dependent)を用いた。ま ず，被検者の頭部を体表面上より OM line が垂直にな るように整位し，イヤフォンを装着(課題提示はこの イヤフォンにて行った)，前額部および下顎をテープ で固定した。機能画像収集の前に位置決め用のT1強調 型グラディエントエコー法の正中久状断面とspin echo 法による $\mathrm{T}_{1}$ 強調画像の水平断面を撮像 $(\mathrm{TR} 400 \mathrm{~ms}$, $\mathrm{TE} 10 \mathrm{~ms}, 192 \times 256$ マリクス, 積算回数 1 回, FOV $240 \mathrm{~mm}$ ) し，BOLD信号を得るスライス範囲を決 定した。基準線はAC-PCline（前交連と後交連を結ぶ 線)とし，これに平行な撮像断面で, 外側溝 (一次聴覚 野)を含むレベルから頭頂側(側脳室上部を含む)へ4 スライスを設定した。賦活パラダイムのデザインは box-car paradigm (Fig. 1)で, 安静30秒一課題30秒を連 続7回， 1 シリーズ 3 分 30 秒の構成で 1 スライス当た り104画像，総計416画像を得た。

\section{1-3 データ解析}

得られたデータをワークステーション (Advantage Workstation Ver.3.1) 八転送し，付属の解析ソフト (functool)にて相互相関解析法 (cross correlation) $(\mathrm{p}<0.001)$ を用い，時間一信号強度変化のグラフおよび 賦活マップを作成した(描出の判定は時間一信号強度変 化として平均 $1.5 \%$ 目安とした)。なお，収集中に発 生した頭部の動きや生理的なノイズ等の補正はシステ ムの構成上やソフト上の制約から行っていない。

\section{2. 結 果}

コントロールとしてFig. 2に課題を与えていないと 
きの信号変化を示す.Fig. 3とFig. 4に同 一健常者での各課題に対する結果の一例 を示す. Fig. 3には「数唱」を行っていると きの関心領域内の時間一信号強度変化の グラフを示してある。脳賦活に伴って明 瞭な信号変化がとらえられていることが 分かる，信号変化としては平均 $2 \%$ であ った(安静時の信号強度の平均と賦活時 の信号強度の平均から算出した值). Fig. 4にはその他の各課題における賦活マッ プを示してある。（a）は聴覚性言語刺激に よる脳賦活マップであり, 两側側頭葉に 賦活が認められた。この領域には一次聴 覚野や聴覚連合野があり，文章の意味理 解や言語の聴覚的理解に関与している ${ }^{10)}$. (b)，(c)，(d)はそれぞれてりとり」, 「五十音」,「自己氏名の復唱」を行ってい るときの脳賦活マップである。「しりと り」では主に左前頭葉や左頭頂葉に賦活 が認められ，「五十音」や「自己氏名の復 唱」でもほぼ同じ部位が賦活されてい た。今回想定した各課題において健常者 で信号変化をとらえることができ，ま た，聴覚性言語刺激を除く各課題とも賦 活部位はほぼ一致していた。なおこの ような明瞭な信号変化は健常者 10 例のう ち8例でとらえられ，施行した課題すべ てにおいて信号変化がとらえられなかっ た健常者は 2 例だった。

一方, 術前の患者では, 今まで施行し てきた「しりとり」15例のうち信号変化が とらえられたのは 2 例 (右側頭葉, 左側 頭葉に病巣がある患者)で，課題を選択 させた患者では10例のうち 8 例であっ た. 8 例の内訳は「自己氏名の復唱 $」 1$ 例 (病巣：右側頭葉)，「しりとり」2 例 (病 巣: 右側頭葉, 左側頭葉), 「数唱」4 例 (病巣: 右前頭葉, 右頭頂葉, 左前頭 葉, 左側頭葉), 聴覚性言語刺激 1 例 (病 巣: 左側頭葉)であった. 信号変化とし ては平均 $1.5 \%$ であった。残り 2 例(病 巣: 右前頭葉, 左前頭葉) は信号変化が とらえられなかった. Fig. 5 に臨床例を 示す. Fig. 5は24歳, 女性. 左側頭葉に 腫瘍がある患者で，「五十音」と「数唱」で 選択を迷った例である。なお，背景に30 秒から 1 分間の失語発作がある。「五十 音」(Fig. 5a)施行中の関心領域内の信号強

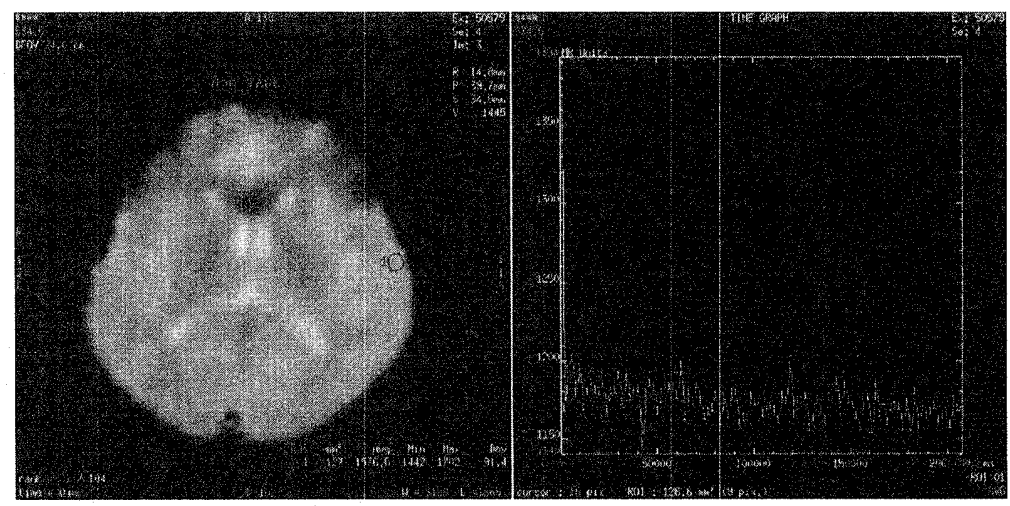

Fig. 2 An image taken as a control shows a signal shift in the same subject at a time when no activity was being administered.

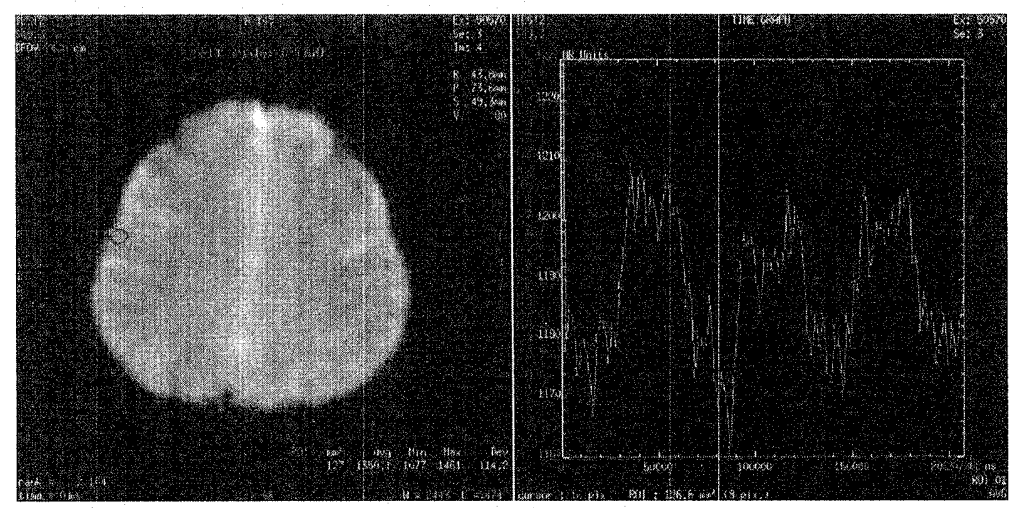

Fig. 3 Shift in signal strength during the "count aloud" activity.

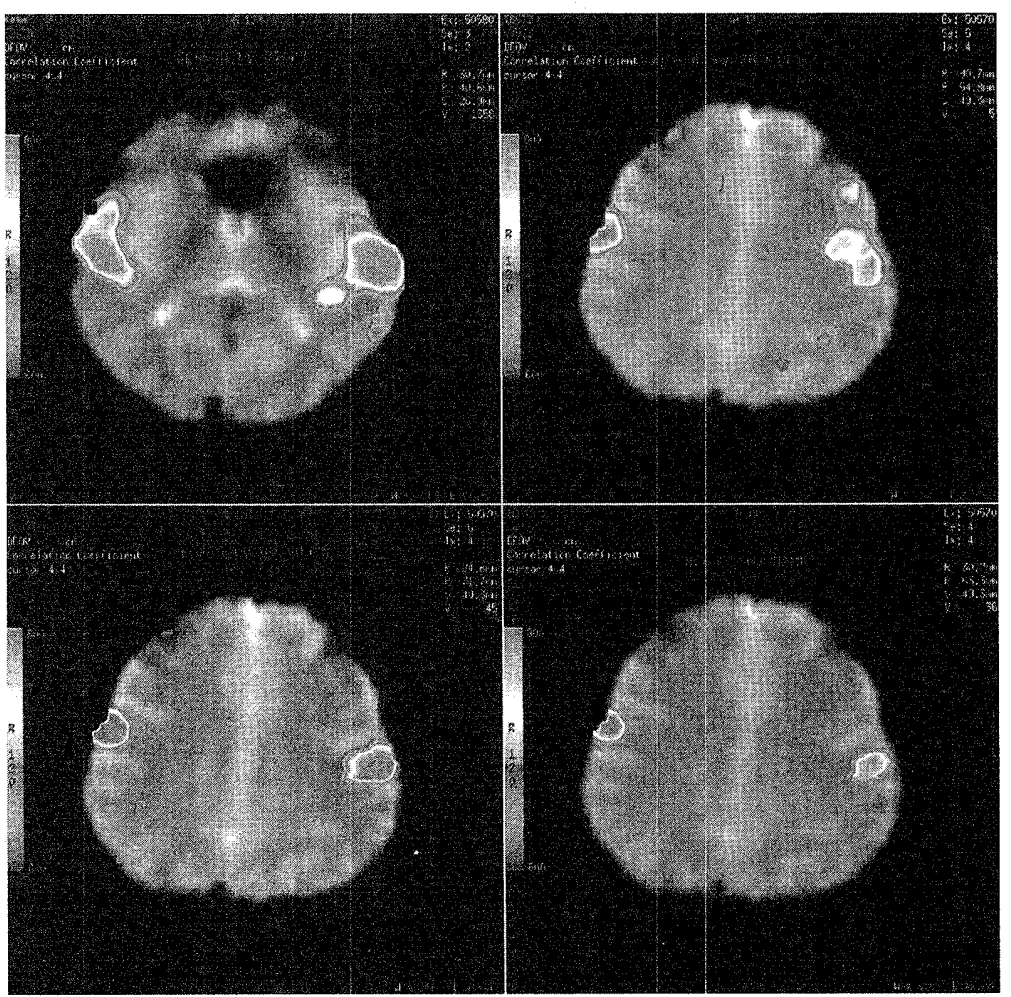

Fig. 4 Activation maps obtained during (a) stimulus of the language function by hearing, (b) "shiritori," (c) "pronounce the Japanese syllabary," and (d) "give your name" activities (corrected p-value $<0.001$ ). 

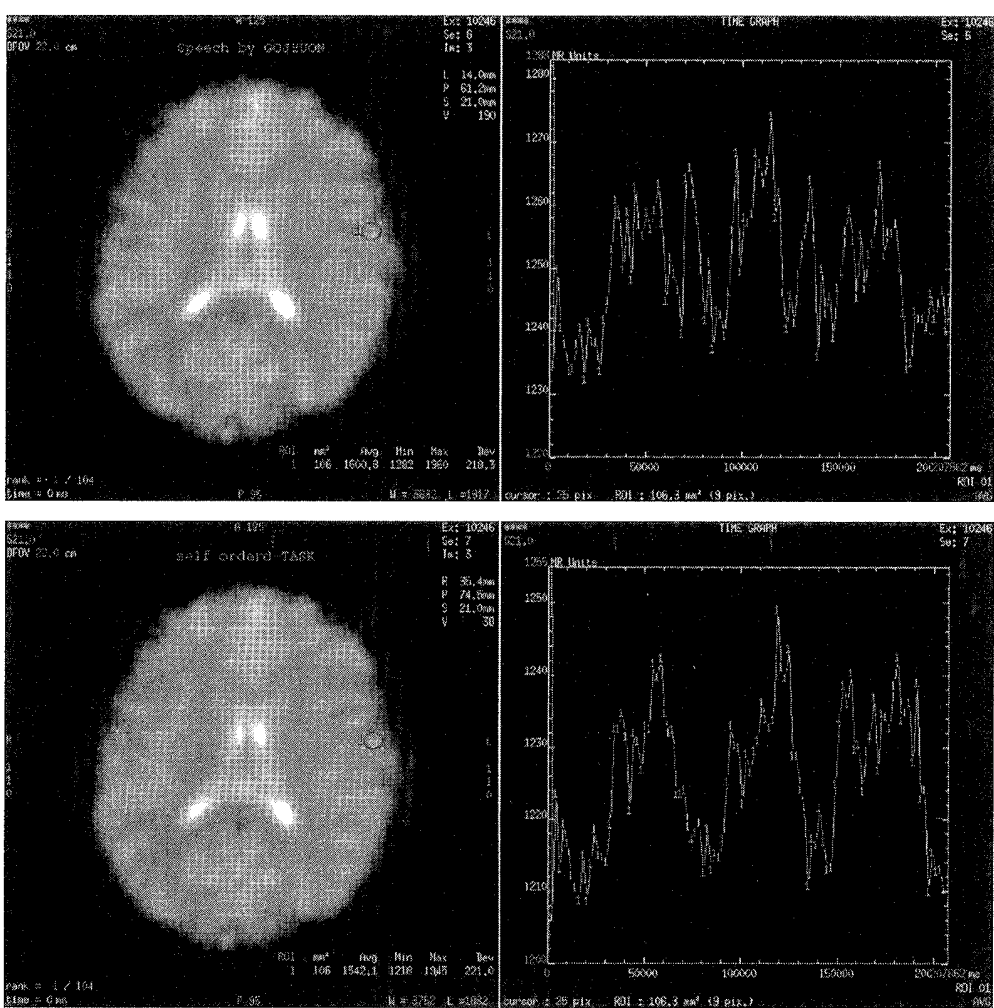

Fig. 5 (a) Shift in signal strength during "Japanese syllabary" activity.

(b) Shift in signal strength during "count aloud" activity.

Tumor in left tenporal lobe.

This 24-year-old woman suffered from temporary aphasia lasting from 30 to 60 seconds. She could not choose between the "pronounce the Japanese syllabary" and "count aloud" activities, so both were performed. The signal shift seen during the "count aloud" activity appears to be coordinated with brain activity.

度変化をみると，課題に伴った信号変化を確認できる が，安静時の信号も高く不安定であることが分かる. 一方, Fig. 5bは「数唱」施行中の信号強度变化であり, 「五十音」施行中より安静時の信号变化も安定していて かつ課題に伴った变化を示している. 今回の検討では Fig. 5bのような信号変化を示す場合を解析に使用し た.

\section{3. 考 察}

fMRIが臨床に応用され始めて 8 年近くが経過して いる. 一次運動野や視覚野の描出から言語や認知・学 習といったより高次機能の描出へと応用され, 課題に 何を用いるかが重要となっている. 手・指の運動賦活 の信号変化は完全な麻痺でない限り, 臨床でも信号変 化は得られるが，「しりとり」を課題とした言語賦活で 信号変化がとらえられたものは15例のうち 2 例のみと 少なかった。これは与える課題に問題がある可能性が あり，対象者が達成できなかったということも考元ら れる．今回の検討では課題をあらかじめ決めてしまう
のでなく，患者に選択させることで，対 象者自身が達成可能な課題を選択できる ことになる. 少なくとも課題が達成でき なかったことによる検査不成功という面 は最小限にとどめることができる。

わが国では「しりとり」を課題として用 いたほうがよいという報告7,8)もあり，わ れわれも fMRIを始めた当初から施行して きた，しかし，手技上の問題もあるのか 特に臨床では信号変化をとらえたものは 少なかった，対象者によっては「しりと り」を行うことが困難であった場合も十 分考えられる。 そこで今回は対象者自ら 自分に合った課題を選択してもらう方法 をとることにした，結果に示す通り，課 題を選択させることで10例中 8 例に扔い て信号変化をとらえることができた。特 に「数唱」を選択した患者 5 例は全例描出 可能であった，信号变化が確認できなか ったのは「しりとり」と「自己氏名の復唱」 を選択した 2 例であった。今まで行って きた「しりとり」15例では 2 例のみの描出 であり, 今回の方法でよい結果が得られ たことは明白である。

また病巣の局在部位との関連でみる と, Table 2から分かるように，「しりと り」を課題とした15名のうち10名は前頭 藥に病巣があり, 課題を選択させた 10 名 のうち 6 名は側頭葉に病巣があることが 分かる. 神経心理学の分野では詳細な検討がなされて おり ${ }^{11}$ ，呼称障害は側頭葉損傷によって最も大きいこ とや，前頭葉損傷では語頭音による語流暢性が低下す ることなど言語機能について梁く解明されている。こ れらのことと今回の結果をすぐに結び付けることはで きないが，少なくとも脳内疾患の局在部位によって， 損傷される言語機能を事前に把握することも可能であ り, 課題の種類を損傷部位ごとに変えることも一つの 方法であると思われる。この点については今後検討す る必要がある。

今回の試みでは課題として「数唱」を選択した場合に 安定した結果が多く得られたが，これは「しりとり」に は個人の語彙数や生活環境が関与してしまい, 課題達 成の点で不利なことが考えられる。また，数を数える という行為は日常生活で最も頻繁に行われることか ら，課題として選択した患者が多かったものと思われ る．ただし，患者とのコミュニケーションがとれない 場合には別の課題を考光る必要があり, 言葉の理解が 保たれていれば，聴覚性言語刺激は有用な課題であ 
る。この課題では意思蹯通が困難であっても信号変 化がとらえられ，言語優位半球の同定も可能であっ た9,10), また側頭葉に病巣がある場合, 病巣との位置 関係の把握も可能であった。なお今回想定した課題の うち，動物名想起を選択した対象者がいなかったが, これは「しりとり」以上に難しいという意見が多かっ た。

今回，課題を選択させることで明らかに描出率の向 上がみられた。 fMRIにおいては与えた課題が達成で きなければ結果が得られないため, 原則として, 対象 者が達成しやすい課題を組み立てるという個人に対す る配慮が臨床では最低限必要であると思われる。さら に，今回検討した課題では「数唱」と「聴覚性言語刺激」
は臨床で使用する課題として有用であると思われる。

\section{4. 結 語}

fMRIを用いて言語野を描出する場合, 臨床に適し た課題設定の検討を行った。今回は課題に選択肢を設 けることで, 個人がより達成可能な課題を使用して検 查が施行できる。言語野描出には年齢や個人の語彙 数，生活環境など個人に対する配慮が必要であり，個 人が達成できる単純な課題を組み立てることが臨床で は重要な点である。また，今回の検討した課題では 「数唱」と「聴覚性言語刺激」が臨床で用いる課題として 有用なものであった。

\section{参考文献}

1）中井敏晴, 松尾香弥子, 加藤知佳子, 他：核磁気共鳴法を 用いた脳機能測定法 (fMRI) の方法論入門. 認知科学, 5 (3) , 100-118, (1998).

2) 加藤俊徳 : 脳のイメージングupdate一解剖から治療まで一 高次機能のfMRIヒト・メンタルオペレーション・システム の視覚化. 臨床放射線, 44(11)，1251-1263，(1999).

3）伊藤浩介, 藤井幸彦, 中田力：fMRIで得られた情報。臨 床神経科学, 17(12)，1357-1362，(1999)。

4) 中田 力：高磁場functionalMRIの現状。臨床神経科学, 18 (9), 1030-1033, (2000).

5) 中田 力：磁気共鳴機能画像. 第18回Radiology Update学 術講演会, 東京, 5-9, (1998)。

6）中田 力：fMRI：実践のための基礎知識. 日本生理誌,
61, 155-168, (1999).

7）杉下守弘：functionalMRIの現状と将来への展望, ファンク ショナルMRIによる言語機能へのアプローチ．失語症研 究, 19(3)，157-162，(1999).

8) 杉下守弘：functionalMRIによる言語研究の展開. 脳の科 学, 98年増刊号, 135-140, (1998).

9) 田中忠蔵, 福永雅喜, 恵比寿俊彦, 他 : FunctionalMRIの 基礎と臨床。脳神経外科ジャーナル，9(7)，497-503, (2000).

10)本庄 嚴：脳からみた言語 脳機能画像からみた医学的ア プローチ。 中山書店, 東京, (1999).

11) 相馬芳明, 本田仁視: 認知神経心理学, 医学書院, 東京, (1996).

Fig. 1 box-car paradigmの概念図.

Fig. 2 課題を与えていないときの時間-信号強度変化のグラフ.

Fig. 3 「数唱」を行っているときの関心領域内の時閒-信号強度変化のグラフ.

Fig. 4 (a)「聴覚性言語刺激」，（b)「しりとり」，(c)「五十音」，(d)「自己氏名の復唱」を行わせた時の賦活マップ.

Fig. 5 (a) 左側頭葉腫瘍例.「五十音」施行中の時間一信号強度変化のグラフ.

(b)左側頭葉腫痗例. 「数唱」施行中の時間一信号強度変化のグラフ.

Table 1 対象者が選択した課題.

Table 2 課題に「しりとり」を用いた患者と課題を選択した患者の病巣局在部位. 